\title{
Analysis Juridical Notary Role Of Acquisition Of Assets Of The Debtor As An Alternative Solution Loan Loss (Case Study In Bank Bni Branch Semarang)
}

\author{
Muhammad Wildan Mahindra ${ }^{1}$, Ardi Sanditya ${ }^{2}$ and Munsharif Abdul \\ Chalim $^{3}$
}

Abstract. Banking development shows the dynamics of economic life. Prior to the practice that happens, a lot of problems that arise in the banking one of which is the number of cases of problem loans up to be a bad credit, this raises the firmness of the banks in the lending process. The acquisition made a lot of pros and cons between the customer and the Bank Negara Indonesia (BNI) Branch Semarang

The purpose of this study was to know and analyze the completion of the takeover of Bad Debts Mortgage Assets, identify and analyze the role of the Notary on Takeover Process Mortgage collateral and to know and analyze the obstacles that occur in the process of the takeover of mortgage collateral and settlement with Bank Negara Indonesia (BNI).

This study using sociological juridical approach, the specification is descriptive analytical research, data sources used in the form of primary data obtained through interviews, secondary data with the literature study, qualitative analysis. The problem is analyzed using the theory of implementation and effectiveness of the rule of law.

Based on the results of this study concluded that: 1) The need for a significant settlement between the banks by the debtor in the case of bad credit, the need for new regulations in Credit rescue to prevent possible lossesin a way Rescheduling, re requirements, reordering,2) The role of the Notary, in making this agreement directs, bank at Bank Indonesia Regulation (PBI) on Lending Limit for Commercial Banks and the guidelines for the general bank credit policies SoRegarding intervention of the notary bank credit agreement which refers to the bank's internal rules respectively for the 3) Barriers to solve the problem in bad debts suggesting there should be a code of conduct so that no authority notary public notary so not tricked by the bank.

Keywords: Bad Debt; Foreclosure Of Collateral; Notary Role.

\section{Introduction}

Notary occupy a very important position in the Islamic banking industry at this time, because the notary has a role in making the deed of contracts in Islamic banking products and binding guarantees (especially in the case of Mortgage and Fiducia).

So that agreements have the force of law, should qualify the validity of the agreement contained in Article 1320 of the Code of Civil Code.

Bad loans are non-performing loans which credit card users can not afford the minimum payments that are overdue for more than 3 months. In the banking world, bad debts known as Non-Performing Loan (NPL). If the NPL they are above the limit that has been previously diforecast then the bank could be considered problematic.

Based on the description of the background of the authors are interested in researching and reviewing the role of the notary in the takeover of assets Debtors on bad credit that existed at PT Bank Negara Indonesia, based on the perspective of Act No. 10 of 1998 on Banking, for the author will take the title of the study are: "Analysis Juridical Notary Role

\footnotetext{
1 Students Master of Notary, Sultan Agung Islamic University Semarang, wildan.mahendra098@gmail.com

${ }^{2}$ Students Master of Law, Sultan Agung Islamic University Semarang, ardidevazaki88@gmail.com

${ }^{3}$ Faculty of Law Universitas Islam Sultan Agung
} 
Of Acquisition Of Assets Of The Debtor As An Alternative Solution Loan Loss (Case Study In Bank Bni Branch Semarang)".

This study intends to answering the problems (1) How Bad Debt settlement with the Asset Acquisition of Mortgage PT. Bank Negara Indonesia (BNI) Branch Semarang, What is the Role Notary in the takeover of mortgage collateral ?; (2) What are the obstacles that occur in the process of taking over the assets of the collateral?

\section{Research methods}

The method in this study, using the Qualitative Research Methods sociological juridical approach, descriptive analytical research specifications, the type of data source materials of primary law, secondary law material and tertiary legal materials. The location was chosen in this study is PT. Bank Negara Indonesia Branch Semarang Jl. MT Haryono No. 16 Semarang.

\section{Results And Discussion}

\subsection{Bad Debt Settlement with Mortgage Asset Acquisition of PT. Bank Negara Indonesia (BNI) Branch Semarang}

As one of the state-owned banks, BNI continue to strive for meeting the needs of society. One of them held a Bank BNI loans. "Bank BNI also ogled by many people. Because, BNI provides loans of up to Rp 5 billion with a tenor of up to 20 years installment. BNI also offers loans for pensioners with the requirements of an easy and attractive benefits really. for which you want to know, here are four types of Bank BNI loans which can be selected according to the needs " 4 this is the number of customers who borrow without seeing the inherent risks in the face of financial crisis

\subsubsection{Type of Credit Products at PT. Bank Negara Indonesia (BNI) Branch Semarang}

Below is described kinds - types of credit in Bank BNI Branch Semarang :

Figure 2.1. Personal Services Bank BNI Branch Semarang

\begin{tabular}{|c|c|c|c|}
\hline Type of & \multicolumn{3}{|c|}{ Service } \\
\hline Loan & $\begin{array}{ll}- & \text { BNI Griya } \\
\text { - } & \text { BNI Griya Multifunction } \\
\text { - } & \text { BNI Flexi }\end{array}$ & $\begin{array}{l}\bullet \\
\bullet \\
\bullet\end{array}$ & $\begin{array}{l}\text { BNI Instant } \\
\text { BNI Flexi Retirement } \\
\text { BNI KUR }\end{array}$ \\
\hline
\end{tabular}

\subsubsection{Credit Application Procedures On Bank BNI Branch Semarang}

Customers who come to Bank BNI Branch Semarang to credit is certainly not directly provided by the bank for granted. Banks need more information about the data owned by the candidate receiving the credit. Completeness of customer documents, review of customer's business Analyzing the customer's business.

Other terms in accordance with the existing Implementation Manual (SOP) Bank BNI which must be completed by the customer / debtor among others: identification cards; WajibPajak Identification Number (TIN); Sural location permit (AIS); Establishment Business License; Certificate of Company Registration; Deed of incorporation; The financial statements of the last 3 years.

\footnotetext{
${ }^{4}$ Interview with Ms. Vivi Novian As Account Officer PT Bank Negara Indonesia Branch Semarang, dated August 13, 2019
} 
Procedures for the submission of credit: Prospective borrowers experience Emitter line of business (minimum 3 years), (document legal ownership and its value is sufficient), Candidate debtor filed an application for credit to banks that are equipped with the data of its business activities 3 (three) years, data request existing customers will complete has been processed / analysis by the bank. ${ }^{5}$

\subsubsection{Credit Guarantees are in deposit}

Credit guarantees in Bank basically can be deposit: ${ }^{6}$ Security people (avalist / borgtocht) that is on the provision of credit to the person guaranteed by others, collateral in the form of securities, such as a letter of deposits, money orders, bank certificates, government bonds maturing, guarantee the goods may be goods movable or bergcrak, guarantee for individual customers / individuals that deed of land and buildings, guarantee for the company that is the land deed and corporate buildings and businesses in the form of securities owned by the company.

\subsubsection{Procedures for Troubled Debt Restructuring In Bank BNI Branch Semarang}

Loan resolution efforts by Bank BNI Branch Semarang when collateral of the debtor after the sale are not sufficient to repay the loan at the Bank is urging debtors to sell and deliver the results to Bank BNI as repayment.

- If the deal is approved then the agreement will be notified in writing to borrowers.

- If borrowers do not carry out its obligations as an agreement.

- In case of default from the date of entry into force of the agreement, the deal is void and obligations of borrowers to the original agreement in accordance debentures.

The efforts of banks to think and find a way to be able to do the rescue program loans are often knock to the difficulties as follows: Prospects debtor is still good, the difficulty to find partners who are willing and able to raise capital (fresh money), difficulty looking for buyers in the framework of the debtor company asset sales, in the case of credit berbcntuk credit syndicate. not obtained the agreement and the syndicated banks regarding the terms of the rescue loan.

Giving credit to the customer sometimes regardless of credit management consequently and consistently. This causes the part of credit control is not working properly resulting in the repayment of credit increasingly difficult. ${ }^{7}$

Every credit must be stated in the credit agreement in writing. Bank Negara Indonesia, shape and material loan agreement between the bank and the Customer is not the same, Bank BNI submit completely to the part of credit to determine the form and format of agreements credit records should be at least mcmperhatikan things that are not contrary to Regulation Agreement contained in Act No. 10 of 1998.

Justice contemplated in this credit in 1313 specified in Article 1 of the Civil Code which states the agreement is an act by which one or more persons bind himself to one or more other people. When explored further include the words dimalan consent or it is in the process of loan agreement.

Of the procedures and measures taken by the Bank mentioned above, the bank resulted in efforts to rescue the credit in the form of: Rescheduling, Requirements back (Recondiiioning), reordering (Restructuring).

Since it is not in accordance with the regulations of Act No. 10 of 1998 on banking, where Article 29 paragraph (4) explain to the interests of customers, banks are obliged

\footnotetext{
${ }^{5}$ Results of interviews with Ms. Vivi Novian, Account Officer of BNI branch Semarang, dated August 13, 2019.

${ }^{6}$ Ibid.

7 Interview with Alridho Arianda as Staff Bussiness Credit Officer of Bank Negara Indonesia Branch Semarang, on August 13, 2019
} 
to provide information on the likelihood of the risk of losses related to customer transactions are conducted through banks ${ }^{8}$

\subsection{The role of the Notary to its participation in the takeover process of mortgage assets}

The presence of the Notary / PPAT is to serve the interests of the community in need of authentic deeds and other documents of authority. Notary / PPAT can be said to be a professional if it is equipped with various scientific capability which can be applied in practice. How to cultivate the values or the provisions of the abstract into a written form (certificate) as desired by the parties.

Credit Agreement between the creditor and the debtor becomes clear because the AJB made, it's called Novation objective. Novation is an agreement that led to the abolishment of an engagement and at the same time raised other arrangement is placed in lieu of the engagement. Objective Novation is the engagement that already exist replaced with other engagements. Creditors and debtors make a new covenant, by which abolished the old covenant, in the case of foreclosed assets above, the Credit Agreement between the creditor and the debtor to remove because the Sale and Purchase Agreements (AJB). ${ }^{9}$

Therefore the legal protections that apply not been realized, and contrary to the rules of Act No. 2 of 2014 On Notary.

Notary plays along on the people, for the benefit of whom the deed was made, notary acts throughout the place, where the deed was made and notary acts along the locus of the deed. The legal consequences arising out of the deed in Bank financing agreement is that the authorities make an authentic deed is a notary public, with the exception of the authority handed over to officials of another or others.

For example, because the letter of guarantee is problematic, but the bank is forced to make a notary deed. in making the loan agreement, the bank should refer to Bank Indonesia Regulation (PBI). The regulations are PBI 7/3 / PBI / 2005 regarding Legal Lending Limit for Commercial Bank and SK Dir BI No. 27/162 / KEP / DIR dated March 31, 1995 regarding the credit policy guidelines for the commercial banks. ${ }^{10}$

\subsection{Barriers that occur in the process of acquisition of the asset encumbrance}

Lending activity by banks to borrowers in essence has the aim of helping the economy of the community, especially businesses such as merchants, artisans and other small businesses. Most small entrepreneurs have little working capital, therefore, with the lending objective is to develop small business entrepreneurs are becoming more advanced than ever before. In addition, lending activity for banks aiming to perform its function as Intermediaries Public Finance (Financial Intermendiary), the bank became a media intermediary parties that have excess funds (surplus offounds) with parties that lack / need funding (lack founds ).

Barriers to Process Credit Restructuring troubled There is the most dominant are the obstacles in the process of restructuring of problem loans at Bank Negara Indonesia, namely: The debtor is not acting in good faith, the Debtor having economic problems, not

\footnotetext{
${ }^{8}$ Results of interviews with Ms. Vivi Novian. Bank Account Officer BNI branch Semarang, dated August 13, 2019,

${ }^{9}$ Results of an interview with Mr. Kristiono as Team Leader Business Banking Center (BBC) PT. Bank Negara Indonesia Branch Semarang, dated August 13, 2019

10 Sihadibroto, Kartini Soedjcndro. 2006, Kredit Macet Tinjauan Hukum dan Penyelesaiannya. edisi pcrlama, Yayasan Widya Pallia. Yogyakarta, p. 50-51
} 
able to complete the documents that must be met as a condition for lending in Bank Negara Indonesia (BNI) Branch Semarang.

- Granting bail to the implementation of credit by the debtor is not supported by the documents are complete, so that the bank can not accept such assurances as a condition for granting the credit.

- Debtors will be given credit by BNI Semarang not corporative pensurveian through the process so it tends to cover up data that should be provided by the debtor

Credit to the bank as creditor has seen since the pre-stage of restructuring. Borrowers / debtors do not take the initiative and actively negotiating with the bank as creditor.

Another obstacle encountered in the field by the State Bank BNI branch Semarang against debtors is that the debtor seeks to secure assets that is not known by the bank, resulting in the implementation of the restructuring by the bank debtors as if no longer have other assets that can be to be considered by the bank in the restructuring provision. Debtors tend to be difficult to find by the bank in the implementation of the policy of restructuring negotiations, so that the bank saw the elusive debtor does not deserve to be given the restructuring.

How to overcome barriers that occur on completion of takeover of Collateral on top of the bank as creditor aka take steps to not restructure problem loans of the borrowers when they are proven to significantly borrowers do not have good faith in making the settlement payment of credit obligations.

\section{Closing}

\subsection{Conclusion}

- Bad Debt Settlement with Mortgage Asset Acquisition of PT. Bank Negara Indonesia (BNI) Branch Semarang. If credit has been given no indication it becomes troubled bank can carry out repairs as soon as possible penyeiamatan and credit rescue to prevent the possibilities of further losses on noncurrent loans that is : Rescheduling (Rescheduling), Requirements back (Recondiiioning), reordering (Restructuring).

- Process Notary role in the takeover of mortgage collateral. There are 2 (two) ways to run the process of foreclosed assets, the first through the auction followed by making the minutes of the auction under the authority of the Notary, then the second through voluntary transfer of the debtor to the creditor by making agreements Sale and Purchase Agreement (SPA) and the Power to sell the authority of the Notary and then proceed with the manufacture of Sale and Purchase Agreements (AJB) which is authorized PPAT.

- Barriers that occur in the process of takeover of mortgage assets. Borrowers as borrowers seek to provide false information on the condition of the company so as if the condition of the company experiencing economic difficulties, but the condition that they are not. It is intended by the borrowers as the debtor so that borrowers can defer loan payment obligations that may be given waivers by the bank in the implementation of debt restructuring by slashing interest installment has been in arrears.

\subsection{Suggestion}

- The final decision on lending conducted by the credit pengelolah, therefore credit pengelolah part must be firm in making decisions.

- Improving the Precautionary Principle on Notary authorized the finalization of the takeover of the collateral in Bank Negara Indonesia, and review of the new agreements held by banks in this case against the collateral bad credit borrowers will be taken over.

- It should be for borrowers whose bad faith in implementing the debt payment obligations to the Bank Negara Indonesia (BNI) Branch Semarang as creditor taken firm 
action by the bank by way of legal proceedings in accordance with the legislation in force.

- Should the implementation of the troubled debt restructuring undertaken by Bank Negara Indonesia (BNI) Branch Semarang pursued in real terms and conditions of debt obligations in terms of borrowers (debtors) who have difficulty paying it.

\section{Bibliography}

Books

[1] Andasasmita, Komar, 1984, Notaris I, Sumur Bandung.

[2] Anton Suyatno, 2018, Kepastian Hokum dalam Penyelesaian Kredit Macet, Prenamedia Grup, Depok.

[3] Cst Kansil, et. all., 2009, Kamus Istilah Hukum, Jala Permata Aksara, Jakarta.

[4] Djoni S Gazali, 2012, Hukum Perbankan, Sinar Grafika, Jakarta.

[5] Dr Habib Adjie, 2015, Penafsiran tematik hukum notaris indonesia, PT Refika Aditama, Bandung

[6] Kasmir, 2009, Bank dan Lembaga Keuangan Lainnya, Raja Grafindo Persada, Jakarta.

[7] Hermansyah, 2005, Hukum Perbankan Nasional Indonesia, Sinar Grafika, Jakarta.

[8] M. Yahya harahap, 2002, Pembahasan Permasalahan Dan Penerapan KUHP Penyidikan dan Penuntutan, Sinar Grfika, Jakarta.

[9] Munif Fuady, 1996, Hukum Perkreditan Kontemporer, Citra Aditya Bakti, Bandung.

[10] R. Gatot Supramono, 2009, Perbankan dan Masalah Kredit, Rineka Cipta, Jakarta.

[11] R. Subekti, 2008, Hukum Perjanjian, Sinar Grafika, Jakarta

[12] Satjipto Rahardjo, 2006, Hukum Dalam Jagat Ketertiban, UKI Press, Jakarta.

[13] Soejono Soekamto dan Sri Mamudi, 1995, Penelitian Hukum Normatif Suatu Tinjauan Singkat, PT.Raja Grafindo Persada, Jakarta

[14] Soejono Soekamto, 1986, Pengantar Penelitian Hukum, UI Press, Jakarta.

[15] Sudikno Mertokusumo dalam H. Salim Hs, 2010, Perkembangan Teori Dalam IImu Hukum, PT Raja Grafindo Persada, Jakarta

[16] Sumadi Suryabrata, 1998, Metodologi Penelitian, Raja Gofindo, Jakarta.

[17] Sutan Remy Sjahdeini, 1993, Kebebasan Berkontrak.

[18] Sutarno, 2003, Aspek-Aspek Hukum Perkreditan pada Bank, Alfabeta, Bandung.

Legislation

- Constitution - Constitution of the Republic of Indonesia Year 1945

- Act - the Civil Code / BW (Burgerlijke wetboek).

- The Book of the Law of Commercial Law In 1848,

- Act - Act No. 2 of 2014 Amendment Act

- No. 30 of 2004 concerning Notary

- Act No. 10 of 1998 About Amendment Act - Act No. 7 of 1992 on Banking

- Bank Indonesia Regulation No.14 / 22 / PBI / 2012 dated December 21, 2012 on Lending Or Funding and Technical Assistance in the Context of Development of Micro, Small and Medium Enterprises

- Bank Indonesia Regulation No. 13/27 / PBI / 2011 on Amendment to Bank Indonesia Regulation No.11 / 1 / PBI / 2009 Concerning Commercial Banks

Internet

- http://www.landasanteori.com/2015/10/pengertian-notaris-definisi-syarat.html accessed on April 20, 2019 At 22:01 pm

- https://hukumpress.blogspot.co.id/2016/10/pengertian-tugas-kewenangan-notaris.html 